DOI: https://doi.org/10.31933/jimt.v2i5 Received: 8 April 2021, Revised: 25 Mei 2021, Publish: 17 Juni 2021

JIMT
JURASTII
TERAPAN ILMU MANAJEMEN

\title{
FAKTOR-FAKTOR YANG MEMPENGARUHI ANTI MONOPOLI DAN PERSAIANGAN BISNIS TIDAK SEHAT : GLOBALISASI EKONOMI, PERSAINGAN USAHA, DAN PELAKU USAHA. (LITERATURE REVIEW ETIKA)
}

\author{
Amanda Ayu Rizkia', Suci Rahmawati ${ }^{2}$ \\ 1) Magister Akuntansi , Universitas Mercu Buana ,email : rizkiaamandaayu@gmail.com \\ ${ }^{2}$ Magister Akuntansi , Universitas Mercu Buana , email: rahmawatisuci796@gmail.com
}

\section{Koresponden Penulis: Amanda Ayu Rizkia ${ }^{1}$}

\begin{abstract}
Pertumbuhan berbagai sektor usaha di Indonesia menunjukkan cukup banyak perkembangan pesat, baik di sektor industri maupun jasa, sehingga pada gilirannya persaingan akan muncul yang harus dilihat sebagai hal yang positif, dimana dengan persaingan itu sendiri, para pelaku usaha akan berlomba-lomba untuk terus meningkatkan kemampuannya produk atau jasa yang dihasilkan agar pelaku bisnis terus berinovasi dan berusaha untuk memberikan produk atau layanan terbaik bagi konsumen. Artikel ini mereview Faktor-faktor yang mempengaruhi anti monopoli dan persaingan usaha tidak sehat, yaitu:, Globalisasi Ekonomi, Persaingan Usaha, Pelaku Usaha, suatu studi literatur Manajemen Strategis. Hasil artikel literature review ini adalah: 1) Globalisasi Ekonomi berpengaruh terhadap anti monopoli dan Persaingan Usaha Tidak Sehat; 2) Persaingan Usaha berpengaruh terhadap anti monopoli dan Persaingan Usaha Tidak Sehat; dan 3) Pelaku Usaha berpengaruh terhadap anti monopoli dan Persaingan Usaha Tidak Sehat.
\end{abstract}

Keywords: Anti monopoli dan Persaingan Usaha Tidak Sehat ,Globalisasi Ekonomi, Persaingan Usaha, dan Pelaku Usaha.

\section{PENDAHULUAN \\ Latar Belakang Masalah}

Globalisasi ekonomi sebagai suatu fenomena pada dekade terakhir ini tidak bisa dihindari. Kehadiran Indonesia dalam peta ekonomi, menuntut kemampuan untuk berkembang sebagai suatu kekuatan ekonomibaru. Perkembangan ekonomi yang begitu cepat menuntut kesiapan dan kemampuan pelaku usaha dalam mengikuti perkembangan ekonomi sebagai akibat dari globalisasi ekonomi dunia tersebut.

Perkembangan globalisasi ekonomi tersebut pun membuat dunia usaha yang merupakan suatu dunia yang dapat dikatakan sebagai dunia yang tidak dapat berdiri sendiri untuk berkembang lebih 
pesat lagi. Perkembangan dunia usaha tidak dapat dipungkiri sangat dipengaruhi oleh berbagai faktor baik itu faktor internal maupun eksternal.

Banyak faktor yang terlibat dari berbagai macam dunia lainnya baik yang terkait langsung maupun tidak langsung dalam perkembangan dunia usaha.Keterkaitan tersebut kadang kala tidak memberikan prioritas atas dunia usaha yang pada akhirnya membuat dunia usaha harus tunduk dan mengikuti rambu-rambu yang ada dan seringali mengutamakan dunia usaha sehingga pada akhirnya mengabaikan aturan-aturan yang ada.

Perkembangan dunia usaha baik dahulu, sekarang bahkan sampai kepada masa yang akan datang tidak terlepas dari peran para pebisnis atau pelaku usaha dalam menjalan usaha atau bisnisnya. Cepatnya perkembangan dunia usaha dan disertai tingginya permintaan (demand) pasar atau suatu barangkebutuhan (komoditi) membuat serta mendorong para pelaku usaha untuk mengadakan inovasi secara terus -menerus yang disesuaikan dengan kebutuhan konsumen, sehingga konsumen tidak lari dan dapat membuat pasar menjadi lesu.Banyak peristiwa persaingan usahatidak sehat yang terjadi, sehingga melatar belakangi diangkatnya hal ini sebagai peristiwa yang harus dilakukan penelitian untuk mendapatkan jawaban yang terhadap permasalahan persaingan usaha, sehingga pada akhirnya diharapkan tidak terjadi lagi praktek persaingan usaha tidak sehat khususnya di Indonesia.

Artikel ini menganalisis pengaruh Globalisasi Ekonomi $\left(\mathrm{X}_{1}\right)$ Persaingan Usaha $\left(\mathrm{X}_{2}\right)$, Pelaku Usaha, $\left(\mathrm{X}_{3}\right)$ terhadap Anti monopoli dan persaingan usaha tidak sehat $\left(\mathrm{Y}_{1}\right)$, suatu studi literatur Manajemen Strategis.

\section{Rumusan Masalah.}

Berdasarkan latar belakang akan di rumuskan masalah yang akan di bahas pada artikel literature review agar lebih fokus pada kajian pustaka dan hasil serta pembahasan nanti, yaitu:

1) Apakah Globalisasi Ekonomi memiliki hubungan dan berpengaruh terhadap Anti monopoli dan persaingan usaha tidak sehat.

2) Apakah Persaingan usaha memiliki hubungan dan berpengaruh terhadap Anti monopoli dan persaingan usaha tidak sehat.

3) Apakah Pelaku usaha memiliki hubungan dan berpengaruh terhadap Anti monopoli dan persaingan usaha tidak sehat.

\section{KAJIAN TEORI}

\section{Anti monopoli dan persaingan usaha tidak sehat.}

Muliyawan, S.H., M.H., ( 2015 ) menyatakan bahwa Persaingan usaha yang tidak sehat akan melahirkan monopoli. Bagi para ekonom defenisi monopoli adalah suatu struktur pasar dimana hanya terdapat satu produsen atau penjual. Sedangkan pengertian monopoli bagi masyarakat adalah adanya satu produsen atau penjual yang mempunyai kekuatan monopoli apabila produsen atau penjual tersebut mempunyai kemampuan untuk menguasai pasar bagi barang atau jasa yang diperdagangkannya, jadi pada dasarnya yang dimaksud dengan monopoli.

Menurut Alfa Aprias bahwa "Pesatnya perkembangan dunia usaha adakalanya tidak diimbangi dengan "penciptaan" rambu-rambu pengawasan. Dunia usaha yang berkembang terlalu pesat sehingga meninggalkan rambu-rambu yang ada jelas tidak akan menguntungkan pada akhirnya. Apabila hukum tidak ingin dikatakan tertinggal dari perkembangan bisnis dan dunia usaha, maka hukum dituntut 
untuk merespon segala seluk beluk kehidupan dunia usaha yang melingkupinya sebagai suatu fenomena atau kenyataan sosial. Itu berarti, peran hukum menjadi semakin penting dalam menghadapi problema-problema dunia usaha yang timbul seperti monopoli dan persaingan usaha tidak sehat" (Alfa Alprias, 2010 : 1) Lebih lanjut Alfa Aprias mengatakan "monopoli menggambarkan suatu keadaan dimana terdapat seseorang atau sekelomok orang yang menguasai suatu bidang tertentu secara mutlak, tanpa memberikan kesempatan kepada orang lain untuk ikut ambil bagian. Monopoli diartikan sebagai hak istimewa (previlege), yang menghapuskan persaingan bebas, yang tentu pada akhirnya juga akan menciptakan penguasaan pasar. Persaingan usaha tidak sehat adalah suatu bentuk yang dapat diatikan secara umum terhadap segala tindakan ketidakjujuran atau menghilangkan persaingan dalam setiap bentuk transaksi atau bentuk perdagangan dan komersial. Adanya persaingan tersebut mengakibatkan lahirnya perusahaan-perusahaan yang mempunyai keinginan yang tinggi untuk mengalahkan pesaing-pesaingnya agar menjadi perusahaan yang besar dan paling kaya"

Ketika persaingan meningkat, perusahaan memberikan insentif yang lebih lemah karena manajer secara implisit termotivasi untuk bekerja lebih keras. Misalnya, Hart (1983) menunjukkan bahwa persaingan yang lebih besar memberikan insentif manajerial implisit yang lebih kuat, karena pemain pasar tambahan membuat perusahaan mendapatkan informasi yang lebih baik dan dengan demikian lebih mampu mengevaluasi tindakan manajer. Demikian juga, Schmidt (1997) menunjukkan bahwa peningkatan persaingan meningkatkan kemungkinan likuidasi dan oleh karena itu insentif yang lebih besar bagi manajer, yang bekerja lebih keras untuk mempertahankan pekerjaan mereka. Untuk menguji hubungan antara persaingan dan konsentrasi, pertimbangkan apa yang terjadi ketika produk dapat diganti dalam suatu industri meningkat. Ketika pergantian produk meningkat, begitu pula persaingan harga hal ini memaksa perusahaan yang kurang efisien yang tidak dapat menjaga biaya tetap rendah untuk keluar dari industri atau bergabung dengan perusahaan yang lebih efisien, dalam jangka panjang. Lebih lanjut, peningkatan persaingan ini dapat menghalangi perusahaan potensial memasuki industri. Akibatnya, industri berakhir dengan lebih sedikit perusahaan dan konsentrasi yang meningkat. Perusahaan yang tersisa menghadapi peningkatan permintaan untuk produksi dan karenanya memberikan manajer insentif yang lebih kuat untuk mengurangi biaya marjinal (Hotelling, 1929; Salop, 1979).

Ketika persaingan meningkat, perusahaan memberikan insentif yang lebih lemah karena manajer secara implisit termotivasi untuk bekerja lebih keras. Misalnya, Hart (1983) menunjukkan bahwa persaingan yang lebih besar memberikan insentif manajerial implisit yang lebih kuat, karena pemain pasar tambahan membuat perusahaan mendapatkan informasi yang lebih baik dan dengan demikian lebih mampu mengevaluasi tindakan manajer. Demikian juga, Schmidt (1997) menunjukkan bahwa peningkatan persaingan meningkatkan kemungkinan likuidasi dan oleh karena itu insentif yang lebih besar bagi manajer, yang bekerja lebih keras untuk mempertahankan pekerjaan mereka. Untuk menguji hubungan antara persaingan dan konsentrasi, pertimbangkan apa yang terjadi ketika produk dapat diganti dalam suatu industri meningkat. Ketika pergantian produk meningkat, begitu pula persaingan harga hal ini memaksa perusahaan yang kurang efisien yang tidak dapat menjaga biaya tetap rendah untuk keluar dari industri atau bergabung dengan perusahaan yang lebih efisien, dalam jangka panjang. Lebih lanjut, peningkatan persaingan ini dapat menghalangi perusahaan potensial memasuki industri. Akibatnya, industri berakhir dengan lebih sedikit perusahaan dan konsentrasi yang meningkat. Perusahaan yang tersisa menghadapi peningkatan permintaan untuk produksi dan karenanya memberikan manajer insentif yang lebih kuat untuk mengurangi biaya marjinal (Hotelling, 1929; Salop, 1979). 
Anti monopoli dan persaingan usaha tidak sehat sudah banyak di teliti oleh peneliti sebelumnya diantaranya adalah: ( pengawas K., Usaha P., Indonesia R. , 2011) , ( Zulfiani Z. , 2016).

\section{Globalisasi Ekonomi}

Waters mendefinisikan globalisasi dari sudut pandang yang berbeda. Dia mengatakan bahwa globalisasi merupakan sebuah proses sosial, dimana batas geografis tidak penting terhadap kondisi sosial budaya, yang akhirnya menjelma ke dalam kesadaran seseorang. Definisi ini hampir sama dengan apa yang dimaksudkan oleh Giddens. Dimana, globalisasi adalah adanya saling ketergantungan antara satu bangsa dengan bangsa lain, antara satu manusia dengan manusia lain melalui perdagangan, perjalanaan, pariwisata, budaya, informasi, dan interaksi yang luas sehingga batas-batas negara menjadi semakin sempit. Pengertian globalisasi seperti ini juga telah disampaikan oleh beberapa ahli yang mengatakan bahwa globalisasi adalah proses individu, kelompok, masyarakat dan negara yang saling berinteraksi, terkait, tergantung, dan saling mempengaruhi antara satu sama lain, yang melintasi batas negara.

Tomlinson mendefinisikan globalisasi sebagai suatu penyusutan jarak yang ditempuh dan pengurangan waktu yang diambil dalam menjalankan berbagai aktifitas sehari-hari, baik secara fisik (seperti perjalanan melalui udara) atau secara perwakilan (seperti penghataran informasi dan gambar menggunakan media elektronik), untuk menyebrangi mereka.

Menurut Lyman bahwa globalisasi biasanya diartikan sebagai "rapid growth of interdependency and connection in the world of trade and finance". Tetapi, ia sendiri berpendapat bahwa globalisasi tidak hanya terbatas hanya pada fenomena perdagangan dan aliran keuangan yang berkembang dengan kian meluas saja, ini karena adanya kecendrungan lain yang didorong oleh kemampuan teknologi yang memfasilitasi perubahan keuangan, seperti globalisasi komunikasi "there are other trends driven by the same explosion of technological capability that have facilitated the financial change. Globalization of communication is one such trend". Globalisasi dapat dilihat sebagai kompresi ruang dan waktu dalam hubungan sosial dan munculnya kesadaran global tentang kemampatan tersebut. Dalam bahasa seharihari, proses ini bisa dikatakan sebagai "dunia menjadi semakin kecil". Globalisasi dapat juga didefenisikan sebagai proses pertumbuhan dan perkembangan kegiatan ekonomi lintas batas nasional dan regional. Ini diperlihatkan melalui pergerakan barang, informasi, jasa, modal dan tenaga kerja melalui perdagangan dan investasi.

Meskipun gambaran globalisasi dapat dijelaskan secara baik, namun sangat sedikit perhatian yang ditujukan kepada konsep globalisasi dibandingkan dengan pandangan lain yang tersedia dalam teori globalisasi itu sendiri. Menurut Ferguson, pembahasan konsep globalisasi lebih sedikit dibandingkan dengan ungkapan idoelogi kapitalis. Padahal, menurut Bordieu \& Wacquant bahwa konsep globalisasi memiliki pengaruh - jika tidak tepat dikatakan sebagai fungsi - menenggelamkan imperialisme dalam ekumenisme budaya atau fatalisme ekonomi, serta mampu membuat suatu kekuatan hubungan transnasional yang muncul sebagai satu kebutuhan netral.

Globalisasi Ekonomi sudah banyak di teliti oleh peneliti sebelumnya diantaranya adalah: ( winrekso P. , 2017 ), ( Rahardjo M, D. , 2003 ). 


\section{Persaingan Usaha}

Terlepas dari pentingnya pemahaman kita tentang cara kerja persaingan dan implikasi kebijakan ekonominya, secara mengejutkan hanya ada sedikit makalah teoretis tentang subjek ini. Jensen dan Meckling (1976) berpendapat bahwa tingkat persaingan tidak berpengaruh apapun pada biaya agensi. Bagaimanapun, kelonggaran manajerial dinikmati oleh manajer perusahaan, bukan oleh pemiliknya. Oleh karena itu, pemilik monopoli memiliki kepentingan yang sama untuk mengurangi biaya keagenan seperti halnya pemilik perusahaan kompetitif, dan keduanya harus menawarkan skema insentif yang persis sama. Argumen ini mengabaikan, bagaimanapun, bahwa skema insentif yang optimal bergantung pada lingkungan di mana perusahaan beroperasi ( $\tilde{A}, 2007)$ Sebagian besar literatur dimulai dari pengamatan bahwa persaingan menghasilkan informasi tambahan yang tidak tersedia dalam industri monopoli.

Holmstrom (1982) dan Nalebuff dan Stiglitz (1983) menganalisis penggunaan evaluasi kinerja relatif. Jika jumlah pesaing di pasar meningkat, dan jika guncangan yang mempengaruhi biaya masing-masing perusahaan berkorelasi, maka peningkatan persaingan menghasilkan informasi tambahan yang dapat digunakan untuk mengurangi masalah bahaya moral. Sementara gaji pemilik meningkat jika dia dapat memanfaatkan informasi ini, efeknya pada upaya manajerial masih ambigu. Bergantung pada distribusi probabilitas yang mendasarinya, mungkin saja biaya penerapan tingkat upaya yang lebih rendah berkurang lebih dari biaya penerapan tingkat upaya yang lebih tinggi di mana manajer dapat didorong untuk bekerja lebih sedikit. Selanjutnya, performanya relative evaluasi mensyaratkan bahwa gaji manajer bergantung langsung pada kinerja manajer yang bersaing (Schmidt, 1997).

menurut Marbun (2003) adalah usaha dari dua pihak/lebih perusahaan yang masingmasing bergiat memperoleh pesanan dengan menawarkan harga/syarat yang paling menguntungkan. Persaingan adalah ketika organisasi atau perorangan berlomba untuk mencapai tujuan yang diinginkan seperti konsumen, pangsa pasar,peringkat survei, atau sumber daya yang dibutuhkan.Persaingan usaha dilakukan untuk merebut hati konsumen. Para pelaku usaha berusaha menawarkan produk dan jasa yang menarik, baik dari segi harga, kualitas dan pelayanan. Kombinasi ketiga faktor tersebut untuk memenangkan persaingan merebut hati para konsumen dapat diperoleh melalui inovasi, penerapan teknologi yang tepat, serta kemampuan manajerial untuk mengarahkan sumber daya perusahaan dalam memenangkan persaingan.Pelaku usaha jarang sekali hanya berdiri sendiri dalam menjual ke suatu pasar pelanggan tertentu. Perusahaan bersaing dengan sejumlah pesaing. Pesaingpesaing ini harus diidentifikasi, dimonitori dan disiasati untuk memperoleh dan mempertahankan loyalitas pelanggan. Jika terjadi proses persaingan antara para pelaku usaha, maka mereka akan berupaya mencapai tujuannya dengan saling mengungguli dalam mendapatkan konsumen dan pangsa pasar.

Pengertian kebijakan persaingan dalam kamus lengkap ekonomi, karya Christopher pass dan Bryan Lowes adalah kebijakan yang berkaitan dengan meningkatkan efisiensi pemakaian sumber daya dan perlindungan kepentingan konsumen. Tujuan kebijakan persaingan adalah untuk menjamin terlaksananya pasar yang optimal, khususnya biaya produksi yang terendah, harga dan tingkat keuntungan yang wajar, kemajuan teknologi, dan pengembangan produk. 
Sedangkan menurut Hermansyah, pokok-pokok hukum persaingan usaha di Indonesia, menambahkan bahwa kebijakan persaingan usaha adalah kebijakan yang berkaitan dengan masalah masalah Di bidang persaingan usaha yang harus dipedomani oleh pelaku usaha dalam menjalankan usahanya dan melindungi kepentingan konsumen.

Persaingan Usaha sudah banyak di teliti oleh peneliti sebelumnya diantaranya adalah: (Effendi B., 2020 ), ( Darmaryanti H., Utomo S., Annurdi A., 2020 )

\section{Pelaku Usaha}

Pelaku usaha adalah setiap orang perseorangan atau badan usaha, baik yang berbentuk badan hukum maupun bukan badan hukum yang didirikan dan berkedudukan atau melakukan kegiatan dalam wilayah hukum negara Republik Indonesia, baik sendiri maupun bersamasama melalui perjanjian menyelenggarakan kegiatan usaha dalam berbagai bidang ekonomi.

Menurut Mariam Darus badrul zaman mendefinisikan pelaku usaha dengan cara mengambil alih pengertian yang digunakan oleh kepustakaan Belanda, yaitu "semua individu yang menggunakan barang dan jasa secara konkret dan riill".

Menurut Muhammad dan alimin mendefinisikan pelaku usaha berangkat dari pandangan atau konsep Islam terhadap harta, hak dan kepemilikan dengan transaksi atau tidak, sesuai dengan prinsip-prinsip perlindungan konsumen dalam Islam. Definisi pelaku usaha adalah " setiap orang, kelompok atau badan hukum pemakai suatu harta atau jasa karena adanya hak yang sah, baik iya dipakai untuk pemakaian akhir ataupun untuk proses produksi selanjutnya".

Menurut pakar pelaku usaha di Belanda hondius menyimpulkan, para ahli hukum pada umumnya sepakat mengartikan pelaku usaha sebagai pemakai produksi terakhir dari benda dan jasa.

Menurut UU Nomor 5 tahun 1999 tentang larangan praktek monopoli dan persaingan usaha tidak sehat menentukan pegertian "pelaku usaha adalah setiap orang perorangan atau badan usaha, baik yang berbentuk badan hukum atau bukan badan hukum yang didirikan dan berkedudukan atau melakukan kegiatan di wilayah Negara Republik Indonesia, baik sendiri maupun bersama-sama, melalui perjanjian, menyelenggarakan berbagai kegiatan usaha dalam bidang ekonomi".

Sementara itu ruang lingkup yang diberikan Sarjana Ekonomi yang tergabung dalam Ikatan Sarjana Ekonomi Indonesia (ISEI) mengenai pelaku usaha adalah sebagai berikut: a. Investor yaitu pelaku usaha penyedia dana untuk membiayai berbagai kepentingan seperti perbankan, usaha leasing, tengkulak, penyedia dana dan lain sebagainya. b. Produsen, yaitu pelaku usaha yang membuat, memproduksi barang dan/atau jasa dari barang-barang dan atau jasa lain (bahan baku, bahan tambahan/penolong dan bahan-bahan lainnya). Pelaku usaha dalam kategori ini dapat terdiri dari orang/badan usaha yang berkaitan dengan pangan, orang/badan yang memproduksi sandang, orang/badan usaha yang berkaitan dengan pembuatan perumahan, orang/badan yang berkaitan dengan jasa angkutan ,perasuransian, perbankan, orang/badan yang berkaitan dengan obat-obatan, kesehatan dan sebagainya. c. Distributor, yaitu pelaku usaha yang mendistribusikan atau memperdagangkan barang dan/atau jasa tersebut kepada masyarakat. Pelaku usaha pada kategori ini misalnya pedagang 
retail, pedagang kaki lima, warung, toko, supermarket, rumah sakit, usaha angkutan (darat, laut, udara), kantor pengacara, dan sebagainya.

Di dalam peraturan perundang-undangan di Indonesia, istilah konsumen sebagai defenisi yuridis formal ditemukan pada UndangUndang Nomor 8 Tahun 1999 tentang perlindungan konsumen (UUPK) yang menyatakan bahwa konsumen adalah "setiap orang pemakai barang dan/atau jasa yang tersedia didalam masyarakat, baik bagi kepentingan sendiri, keluarga, orang lain maupun makhluk hidup lain dan tidak untuk diperdagangkan”.

Pelaku usaha sudah banyak di teliti oleh peneliti sebelumnya diantaranya adalah: (Artaya, Putu T. P., 2019), ( Ningsih A.S., 2019 ),

\section{METODE PENULISAN}

Metode penulisan artikel ilmiah ini adalah dengan metode kualitatif dan studi literature atau Library Research. Mengkaji Buku-buku literature sesuai dengan teori yang di bahas khusunya di lingkup Manajemen Strategis . Disamping itu menganalisis artikel-artikel ilmiah yang bereputasi dan juga artikel ilmiah dari jurnal yang belum bereputasi. Semua artikel ilmiah yang di citasi bersumber dari Mendeley.

Dalam penelitian kualitatif, kajian pustaka harus digunakan secara konsisten dengan asumsi-asumsi metodologis. Artinya harus digunakan secara induktif sehingga tidak mengarahkan pertanyaan-pertanyaan yang diajukan oleh peneliti. Salah satu alasan utama untuk melakukan penelitian kualitatif yaitu bahwa penelitian tersebut bersifat eksploratif, (Ali \& Limakrisna, 2013).

Selanjutnya dibahas secara mendalam pada bagian yang berjudul" Pustaka Terkait" (Related Literature) atau Kajian pustaka("Review of Literature"), sebagai dasar perumusan hipotesis dan selanjutnya akan menjadi dasar untuk melakukan perbandingan dengan hasil atau temuan-temuan yang terungkap dalam penelitian, (Ali \& Limakrisna, 2013).

\section{PEMBAHASAN}

Artikel ini menganalis dan membahas tentang variabel-variabel Manajemen Strategis yaitu: Globalisasi Ekonomi, Persaingan Usaha, Pelaku Usaha, terhadap Anti monopoli dan persaingan usaha tidak sehat, Riset dan artikel terdahulu dan relevan dengan artikel ini di antarnya adalah:

\section{Pengaruh atau hubungan Globalisasi Ekonomi terhadap anti monopoli dan Persaingan Usaha Tidak Sehat}

Globalisasi ekonomi sebagai suatu fenomena pada dekade terakhir ini tidak bisa dihindari. Kehadiran Indonesia dalam peta ekonomi, menuntut kemampuan untuk berkembang sebagai suatu kekuatan ekonomi baru. Perkembangan ekonomi yang begitu cepat menuntut kesiapan dan kemampuan pelaku usaha dalam mengikuti perkembangan ekonomi sebagai akibat dari globalisasi ekonomidunia tersebut1. Perkembangan globalisasi ekonomi tersebut pun membuat dunia usaha yang merupakan suatu dunia yang dapat dikatakan sebagai dunia yang tidak dapat berdiri sendiri untuk berkembang lebih pesat lagi. Perkembangan dunia usaha tidak dapat dipungkiri sangat dipengaruhi oleh berbagai faktor baik itu faktor internal maupun eksternal. 
Banyak faktor yang terlibat dari berbagai macam dunia lainnya baik yang terkait langsung maupun tidak langsung dalam perkembangan dunia usaha. Keterkaitan tersebut kadang kala tidak memberikan prioritas atas dunia usaha yang pada akhirnya membuat dunia usaha harus tunduk dan mengikuti rambu - rambu yang ada dan seringali mengutamakan dunia usaha sehingga pada akhirnya mengabaikan aturan - aturan yang ada. Perkembangan dunia usaha baik dahulu, sekarang bahkan sampai kepada masa yang akan datang tidak terlepas dari peran para pebisnis atau pelaku usaha dalam menjalan usaha atau bisnisnya. Cepatnya perkembangan dunia usaha dan disertai tingginya permintaan (demand) pasar atau suatu barang kebutuhan (komoditi) membuat serta mendorong para pelaku usaha untuk mengadakan inovasi secara terus - menerus yang disesuaikan dengan kebutuhan konsumen, sehingga konsumen tidak lari dan dapat membuat pasar menjadi lesu.Banyak peristiwa persaingan usaha tidak sehat yang terjadi, sehingga melatar belakangi diangkatnya hal ini sebagai peristiwa yang harus dilakukan penelitian untuk mendapatkan jawaban yang terhadap permasalahan persaingan usaha, sehingga pada akhirnya diharapkan tidak terjadi lagi praktek persaingan usaha tidak sehat khususnya di Indonesia.

Indonesia menganut sistem ekonomi terbuka, yang mengakibatkan lebih mudah dipengaruhi oleh prinsip ekonomi global dan liberalisasi perdagangan, Dalam hal ini, perekonomian Indonesia berhadapan langsung dan terbuka lebar dengan perekonomian negara lain terutama melalui kerja sama ekonomi dengan mitra dagang Indonesia di luar negeri seperti hubungan perdagangan di bidang ekspor-impor, investasi baik yang bersifat langsung maupun tidak langsung,

pinjam meminjam, dan bentuk-bentuk kerja sama lainnya .

Perekonomian Indonesia yang belum stabil saat ini membuat para pelaku usaha cemas, hal tersebut dikarenakan kekhawatiran akan terjadinya gejolak moneter yang akan menimbulkan kesulitan besar dalam dunia usaha antara lain berdampak pada pelaku usaha yang tidak dapat atau diperkirakan tidak dapat memenuhi kewajibannya kepada kreditur asing maupun domestik. Akibatnya krisis ini juga menimbulkan efek negatif terhadap perusahaanperusahaan di Indonesia yang tidak mampu mengembangkan kegiatannya karena terbatasnya sumber dana yang dimiliki dan sistem manajemen perusahaan yang belum memenuhi prinsip-prinsip Good Corporate Governance, dimana seharusnya penerapannya bertujuan sebagai pengaturan internal yang memuat filsafat bisnis perusahaan, panduan nilainilai yang mengatur cara mengelola perusahaan dalam mencapai tujuan bisnis, pedoman menghadapi pelanggan, distributor, pejabat pemerintah, dan pihak-pihak lainnya yang berhubungan dengan perusahaan, termasuk di dalamnya aturan yang mengatur perilaku persaingan sehat dengan pelaku usaha pesaingnya.

Persaingan usaha yang semakin kompetitif dan ditambah lagi lemahnya penerapan Good Corporate Governance, menyebabkan terjadinya keterpurukan dalam sektor ekonomi dan financial di Indonesia. Kondisi diatas menuntut perusahaan untuk selalu mengembangkan strategi perusahaan agar dapat bertahan atau bahkan lebih dapat berkembang dengan cara memperbaiki eksistensi dan kinerjanya. Strategi yang tepat dalam rangka meningkatkan pertumbuhan perusahaan ditempuh dengan melakukan ekspansi baik itu secara internal maupun eksternal.

Globalisasi Ekonomi sudah banyak di teliti oleh peneliti sebelumnya diantaranya adalah: ( winrekso P. , 2017 ), ( Rahardjo M, D. , 2003 ). 


\section{Pengaruh atau hubungan Persaingan Usaha terhadap anti monopoli dan Persaingan Usaha Tidak Sehat}

Persaingan usaha tidak sehat pertama yakni kartel atau hambatan horizontal adalah suatu perjanjian tertulis ataupun tidak tertulis antara beberapa pelaku usaha untuk mengendalikan produksi, atau pemasaran barang atau jasa sehingga diperoleh harga tinggi. Kartel pada gilirannya berupaya untuk memaksimalkan keuntungan pelaku usaha yang mana kartel merupakan suatu hambatan persaingan yang paling banyak merugikan masyarakat, sehingga di antara Undang-Undang Monopoli di banyak negara kartel dilarang sama sekali. Hal ini karena kartel dapat merubah struktur pasar menjadi monopolistik. Kartel juga dapat berupa pembagian wilayah pemasaran maupun pembatasan (quota) barang atau jasa. Dalam keadaan perekonomian yang sedang baik kartel dengan mudah terbentuk, sedangkan kartel akan terpecah kalau keadaan ekonomi sedang mengalami resesi. Selain kartel juga akan mudah terbentuk apabila barang yang diperdagangkan adalah barang massal yang sifatnya homogen sehingga dengan mudah dapat disubstitusikan dengan barang sejenis dengan struktur pasar tetap dipertahankan. Persaingan usaha tidak sehat yang kedua adalah perjanjian tertutup (exclusive dealing) adalah suatu hambatan vertikal berupa suatu perjanjian antara produsen atau importir dengan pedagang pengecer yang menyatakan bahwa pedagang pengecer hanya diperkenankan untuk menjual merek barang tertentu sebagai contoh sering kita temui bahwa khusus untuk merek minyak wangi tertentu hanya boleh dijual di tempat yang eksklusif. Dalam kasus ini pedagang pengecer dilarang menjual merek barang lain kecuali yang terlah ditetapkan oleh produsen atau importir tertentu dalam pasar yang bersangkutan (relevant market). Suatu perjanjian tertutup dapat merugikan masyarakat dan akan mengarah ke struktur pasar monopoli.

Jenis persaingan usaha yang ketiga adalah merger. Secara umum merger dapat didefinisikan sebagai penggabungan dua atau lebih pelaku usaha menjadi satu pelaku usaha. Suatu kegiatan merger dapat menjadi suatu pengambilalihan (acquisition) apabila penggabungan tersebut tidak diinginkan oleh pelaku usaha yang digabung. Dua atau beberapa pelaku usaha sejenis yang bergabung akan menciptakan integrasi horizontal sedangkan apabila dua pelaku usaha yang menjadi pemasok pelaku usaha lain maka akan membentuk integrasi vertikal. Meskipun merger atau pengambilalihan dapat meningkatkan produktivitas pelaku usaha baru, namun suatu merger atau pengambilalihan perlu mendapat pengawasan dan pengendalian, karena pengambilalihan dan merger dapat menciptakan konsentrasi kekuatan yang dapat mempengaruhi struktur pasar sehingga dapat mengarah ke pasar monopolistik.

Persaingan usaha yang tidak sehat akan melahirkan monopoli. Bagi para ekonom defenisi monopoli adalah suatu struktur pasar dimana hanya terdapat satu produsen atau penjual. Sedangkan pengertian monopoli bagi masyarakat adalah adanya satu produsen atau penjual yang mempunyai kekuatan monopoli apabila produsen atau penjual tersebut mempunyai kemampuan untuk menguasai pasar bagi barang atau jasa yang diperdagangkannya, jadi pada dasarnya yang dimaksud dengan monopoli adalah suatu keadaan yang memiliki ciri-ciri sebagai berikut: (1) hanya ada satu produsen atau penjual, (2) tidak ada produsen lain menghasilkan produk yang dapat mengganti secara baik produk yang dihasilkan pelaku usaha monopoli, (3) adanya suatu hambatan baik secara alamiah, teknis atau hukum.

Kalau kita melihat hal tersebut di atas maka ada beberapa faktor yang dapat mengakibatkan persaingan usaha tidak sehat di antaranya adalah (1) kebijaksanaan 
perdagangan, (2) pemberian hak monopoli oleh pemerintah, (3) kebijaksanaan investasi, (4) kebijaksanaan pajak, (5) dan pengaturan harga oleh pemerintah.

Dalam Undang-Undang Nomor 5 Tahun 1999 tentang pengaturan monopoli terdapat 2 (dua) kelompok karakteristik yaitu:

1. kelompok pasal yang memiliki karakteristik rule of reason dan

2. kelompok pasal yang memiliki karakteristik perse illegal

Rule of reason dapat diartikan bahwa dalam melakukan praktik bisnisnya pelaku usaha (baik dalam melakukan perjanjian, kegiatan, dan posisi dominan) tidak secara otomatis dilarang. Akan tetapi pelanggaran terhadap pasal yang mengandung aturan rule of reason masih membutuhkan suatu pembuktian, dan pembuktian ini harus dilakukan oleh suatu majelis yang menangani kasus ini yang dibentuk oleh KPPU (Komisi Pengawas Persaingan Usaha), kelompok pasal ini dapat dengan mudah dilihat dari teks pasalnya yang dalam kalimatnya selalu dikatakan sehingga dapat mengakibatkan terjadinya praktek monopoli atau persaingan usaha tidak sehat.

Sedangkan yang dimaksud dengan perse illegal (atau violation atau offense) adalah suatu praktik bisnis pelaku usaha yang secara tegas dan mutlak dilarang, sehingga tidak tersedia ruang untuk melakukan pembenaran atas praktik bisnis tersebut.

Demikian tulisan singkat ini yang sedikit membahas mengenai persaingan usaha tidak sehat dan praktek monopoli yang terdapat dalam UU Nomor 5 Tahun 1999 tentang Larangan Praktek Monopoli dan Persaingan Usaha Tidak Sehat, semoga menjadi pencerahan bagi kita dalam menjalankan usaha dan dalam rangka menyambut dan menghadapi era pasar bebas kawasan Asia yang tinggal menghitung hari.

Persaingan Usaha sudah banyak di teliti oleh peneliti sebelumnya diantaranya adalah: (Effendi B., 2020 ), ( Darmaryanti H., Utomo S., Annurdi A., 2020 )

\section{Pengaruh atau hubungan Pelaku Usaha terhadap anti monopoli dan Persaingan Usaha Tidak Sehat.}

Hasil penelitian ini menunjukkan bahwa sebenarnya monopoli dan persaingan usaha da pat berjalan secara seiring dalam kegiatan bisnis, karena monopoli bisa bersifat "natural" yaitu dari kegiatan bisnis yang kecil dapat menjadi bisnis yang besar atau sekaligus bisnis raksasa (multinasional).

Hanya kendalanya industri kecil di Indonesia masih berjalan secara konvensional dan tradisional dan kurang greget mencari akses pangsa pasar termasuk akses modal maupun pemasarannya. Oleh karena itu dapat direkomendasikan bahwa pemerintah harus secara terus menerus memperbaiki struktur perekonomian Indonesia agar pelaku usaha dan bisnis dapat berkompetisi secara sehat, fair, dan sistem birokrasi harus ditata dengan lebih baik dan profesional serta memberikan pembinaan dan akses masuk kedalam "industri" kepada pelaku bisnis dengan modal lemah/industri kecil.

persaingan usaha yang sehat merupakan suatu condition sine qua non bagi terselenggaranya ekonomi pasar. Karena itu Undang-Undang (UU) larangan praktek monopoli dan persaingan usaha tidak sehat merupakan suatu kebutuhan dan menduduki 
posisi kunci dalam ekonomi pasar secara marketing. UU ini akan memberikan aturan main yang jelas dan tegas kepada para pelaku usaha dan ekonomi dalam melaksanakan aktivitas usaha, ekonomi dan bisnis mereka. Persaingan antara pelaku usaha salah satunya adalah persaingan dalam merebut pasar dan mendapat konsumen sebanyak-banyaknya.

Persaingan sebenarnya merupakan kondisi ideal yang memiliki banyak aspek positif.Meskipun demikian,persaingan akan dapat berjalan dengan baik sesuai dengan fungsinya apabila tidak terjadi perbuatan curang yang justru merugikan dan menimbulkan aspek negatif. Di dalam fenomena persaingan usaha nasional selalu terdapat isu kondisi struktural ekonomi, isu perilaku mendukung persaingan atau tidak mendukung persaingan dari para pelaku usaha nasional, serta isu kebijakan persaingan usaha nasional. Dalam isu pertama, perspektif ekonomi sangatlah menonjol, untuk isu yang kedua, perspektif ekonomi terkait dengan masalah motif ekonomi dari perilaku tersebut dan sudut pandang hukum akan membahas ada atau tidaknya turan dari perilaku tersebut, sedangkan isu yang ketiga, sangat menonjol perspektif hukumnya.

Oleh karenanya, dalam pembahasan isu persaingan usaha pastinya akan terdapat perspektif ekonomi dan perspektif hukumnya. "Sebagai bentuk penguasaan pasar atas produk tertentu, monopoli bukan saja dapat menarik keuntungan sebesar-besarnya tetapi juga dapat mengganggu dan merusak sistem dan mekanisme perekonomian yang sedang berjalan sebagai akibat distorsi ekonomi yang ditaburkannya, seiring dengan semakin besarnya penguasaan atas pangsa pasar produk tertentu. Sebuah atau beberapa perusahaan yang memonopoli produk tertentu dapat menentukan harga suatu produk sesuka hatinya, karena mekanisme pasar sudah tidak berjalan lagi. Apalagi produk yang dimonopoli itu merupakan kebutuhan primer. Dapat dipastikan mereka dapat mengeruk keuntungan yang sebesarbesarnya. Masyarakat tidak ada pilihan lain kecuali membeli produk monopoli itu" ( Ahmad Yani dan Gunawan Widjaja, 1999 : 3).

Menurut Raha bahwa "jika ditinjau daru UULPM \& PUTS, tindakan pelaku usaha dalam melakukan praktek penguasaan pasar tersebut akan sangat merugikan tidak hanya bagi konsumen tetapi juga bagi pelaku usaha yang lainnnya untuk ikut berpartisipasi dalam pasar yang sama" (Raha, 2011 : 1-2). Lebih lanjut Raha menjelaskan "dengan mengutip pasal 19 UULPM \& PUTS tentang penguasaan pasar, pelaku usaha dilarang untuk melakukan satu atau beberapa kegiatan baik sendiri maupun bersama pelaku usaha lain, yang dapat mengakibatkan terjadinya praktek monopoli dan/ atau persaingan usaha tidak sehat".

Seperti yang disebutkan dalam bagian umum dari penjelasan atas UULPM \& PUTS dan di tegaskan kembali dalam Pasal 3 dari Undang-Undang tersebut, bahwa UU mengambil landasan kepada suatu demokrasi ekonomi berdasarkan Pancasila dan UUD 1945. "Kristalisasinya adalah berupa menjaga keseimbangan antara kepentingan si pelaku usaha dengan kepentingan umum dengan tujuan untuk:1. Menjaga kepentingan umum dan meningkatkan efisiensi ekonomi serta melindungi konsumen. 2.Menumbuhkan iklim usaha yang kondusif melalui terciptanya persaingan usaha yang sehat dan menjamin kepastian kesempatan berusaha yang sama bagi setiap orang. 3.Mencegah praktek-praktek monopoli dan atau persaingan usaha tidak sehat yang ditimbulkan pelaku usaha. 4.Menciptakan efektivitas dan efisiensi dalam kegiatan usaha dalam rangka meningkatkan efisiensi ekonomi 
nasional sebagai salah satu upaya meningkatkan kesejahteraan rakyat".(Munir Fuady :2003:2).

Pelaku usaha sudah banyak di teliti oleh peneliti sebelumnya diantaranya adalah: (Artaya, Putu T. P., 2019), ( Ningsih A.S., 2019 ),

\section{Conceptual Framework}

Berdasarkan rumus salah penulisan artikel ini dan kajian studi literature review baik dari bukudan artikel yang relevan, maka di perolehan rangka artikel ini seperti di bawah ini.

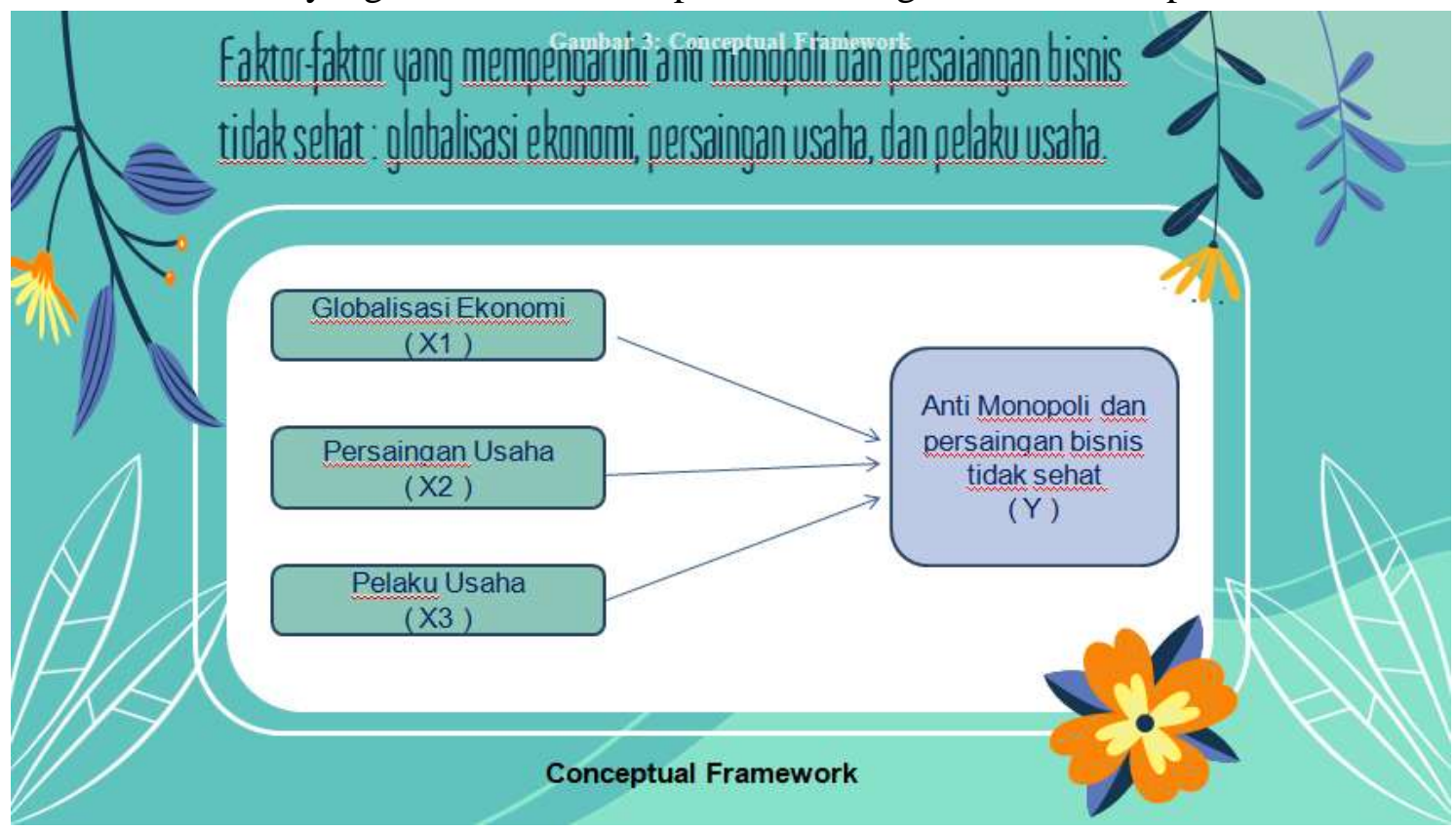

Figure 1: Conceptual Framework

Berdasarkan Kajian teori dan review hasil dari artikel yang relevan serta gambar dari conceptual framework, maka: Globalisasi Ekonomi, Persaingan Usaha, Pelaku Usaha berpengaruh terhadap Anti Monopoli dan Persaingan bisnis tidak sehat.

Selain dari tiga variable exogen ini yang mempengaruhi Anti Monopoli dan Persaingan bisnis tidak sehat, masih banyak variabel lain yang mempengaruhinya diantaranya adalah:

a) Pembangunan X4: ( Suci Y. R., Tinggi S., Ekonomi I. , 2017 ), ( Hidayat A. , 2016 ).

b) Hukum Praktik X5: (( Sukro A. Y., 2019 ), ( Tharifi A. , 2020 ), ( Zulfiani Z. , 2016 ).

c) Perkembangan Ekonomi X6: ( Rahardjo M. D. , 2003 ), ( Saputra I. , 2016 ).

\section{KESIMPULAN DAN SARAN}

\section{Kesimpulan}

Berdasarkanrumusanartikeldanpembahasanmakadapat di dirumuskanhipotesisuntukrisetselanjutnya:

1. Globalisasi Ekonomi (X1) berpengaruh terhadap Anti Monopoli dan Persaingan bisnis tidak sehat $(\mathrm{Y})$. 
2. Persaingan Usaha (X2) berpengaruh terhadap Anti Monopoli dan persaingan bisnis tidak sehat (Y).

3. Pelaku Usaha (X3) berpengaruh terhadap Anti Monopoli dan persaingan bisnis tidak sehat (Y).

\section{Saran}

Bersdasarkan Kesimpulan di atas, maka saran pada artikel ini adalah bahwa masih banyak factor lain yang mempengaruhi Anti Monopoli dan persaingan bisnis tidak sehat pada semua tipe dan level organisasi, oleh karena itu masih di perlukan kajian yang lebih lanjut untuk melengkapi factor-faktor lain apa sajakah yang dapat memepengaruhi Kinerja. Faktor lain tersebut seperti Pembangunan (x4), Hukum Praktik (x5) dan Perkembangan Ekonomi (x6)

\section{DAFTAR PUSTAKA}

Jurnal Ilmiah Niagara Vol. IX No. 1, Juni 2017, strategi pemasaran dalam persaingan dunia usaha, Suhandi, Ilmu Administrasi Niaga Sekolah Tinggi Ilmu Administrasi Banten.

Among Makarti, Vol.4 No.7, Juli 2011, Analisis Faktor Untuk Mengetahui Efektivitas Strategi Me Too Sebagai Strategi Bersaing Perusahaan (studi kasus pada produk sm VIT C 1000 PT. Sido Muncul) oleh Yanuar Surya Putra

Sumber Artikel : Merancang Strategi Pemasaran Untuk Pemimpin, Penantang, Pengikut, dan Perelung Pasar oleh Setia Budhi Wilardjo, VALUE ADDED, Vol.3, No.1, September 2006 \pm Pebruari 2007 http://jurnal.unimus.ac.id

Hermansyah. Pokok-pokok Hukum Persaingan Usaha di Indonesia. Jakarta: Kencana Prenada Media Group, 2008.

Indonesia. Undang-undang Dasar Negara Republik Indonesia Tahun 1945.

Indonesia. Undang-undang Nomor 5 Tahun 1999 tentang Larangan Praktik Monopoli dan Persaingan Usaha Tidak Sehat.

Peraturan Pemerintah Nomor 57 Tahun 2010 tentang Penggabungan atau Peleburan Badan Usaha dan Pengambilalihan Saham Perusahaan Yang Dapat Mengakibatkan Terjadinya Praktik Monopoli dan Persaingan Usaha Tidak Sehat.

Malaka, Mashur. "Praktik Monopoli dan Persaingan Usaha." Jurnal Syariah dan Ekonomi Islam STAIN Kendari Vol. 7 No. 2 (Juli 2014).

Sugiarto, Irwan. "Perspektif Ilmu Ekonomi dan Undang-undang Nomor 5 Tahun 1999 tentang Larangan Praktik Monopoli dan Persaingan Usaha Tidak Sehat Terhadap Diskriminasi Harga." Jurnal Wawasan Hukum Volume 33 Nomor 2 (September 2015).

Yani, Ahmad dan Gunawan Widjaja. Seri Hukum Bisnis: Anti Monopoli, Cetakan Kedua. Jakarta: Rajagrafindo Persada, 2000. 